\title{
Nitrogen metabolism in rumen bacteria can be characterised by their $\mathbf{N}$ isotopic signature
}

G. Cantalapiedra-Hijar*, G. Martinez-Fernandez†, E. Forano ${ }^{\$}$, C. Chantelauze*, C. McSweeney†, D. Morgavi*

*INRA, VetAgro Sup, UMR Herbivores, F-63122 Saint-Genès-Champanelle, France

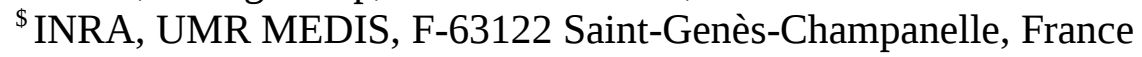

† CSIRO, Queensland Bioscience Precinct, 306 Carmody road, St Lucia, 4067, QLD

\begin{abstract}
The $\mathrm{N}$ use efficiency (NUE) of ruminants is negatively correlated to the natural ${ }^{15} \mathrm{~N}$ enrichment of ruminants' tissues over their diets $\left(\Delta^{15} \mathrm{~N}_{\text {animal-diet }}\right)$. The metabolism of rumen bacteria, which strongly discriminates against ${ }^{15} \mathrm{~N}$ utilisation, may contribute to this link but little is known about the role of individual bacteria. In this study, we characterised the $\Delta^{15} \mathrm{~N}$ of three metabolically different rumen bacteria, a cellulolytic ammonia-consuming, a hyperammonia producing and a proteolytic organism, grown in pure culture with different $\mathrm{N}$ sources and levels. The $\mathrm{N}$ isotopic signatures significantly changed across the 3 rumen bacteria. Although we failed to observe a higher $\Delta^{15} \mathrm{~N}_{\text {bacteria-substrate when proteolysis and }}$ ammonia production was favoured, our results confirm a strong ${ }^{15} \mathrm{~N}$ depletion with the ammonia-consuming bacterium. This may suggest that ${ }^{15} \mathrm{~N}$ depleted ammonia-consuming bacteria improves the NUE in the rumen.
\end{abstract}

Keywords: ${ }^{15} \mathrm{~N}$, ruminant, ammonia, isotopic fractionation

\section{Introduction}

In ruminants, the natural ${ }^{15} \mathrm{~N}$ enrichment of animal proteins over the diet has been proposed as a proxy for $\mathrm{N}$ use efficiency (Cantalapiedra-Hijar et al., 2018). The contribution of rumen microbiota to this link has been acknowledged (Cantalapiedra-Hijar et al., 2016) but the underlying mechanism remains unknown. Based on previous studies we hypothesized that the $\mathrm{N}$ isotopic signature of rumen bacteria $\left(\Delta^{15} \mathrm{~N}_{\text {bacteria-substrate }}\right)$ depends on the balance between uptake and release of ammonia (Martinez-Fernandez et al., 2018), both reactions being catalysed by enzymes discriminating against ${ }^{15} \mathrm{~N}$. Because rumen bacteria differ in their $\mathrm{N}$ metabolism it is expected that $\Delta^{15} \mathrm{~N}_{\text {bacteria-substrate }}$ would reflect their prevailing ability to assimilate or release ammonia. The objective of this study was to evaluate the $\Delta^{15} \mathrm{~N}_{\text {bacteria-substrate }}$ of selected rumen bacteria grown in pure cultures according to their $\mathrm{N}$ metabolism.

\section{Material and Methods}

Three different rumen bacteria strains in terms of $\mathrm{N}$ metabolism were chosen for this study: i) Fibrobacter succinogenes S85 is a cellulolytic bacterium that requires ammonia as source of N (ammonia-N consumer), ii) Clostridium aminophilum (DSMZ 10710) is a hyper-ammonia producing bacterium that uses protein as energy source (ammonia- $\mathrm{N}$ producer) and iii) Prevotella ruminocola (ATCC 19189 ${ }^{\mathrm{TM}}$ ), Prevotella is a predominant rumen genus that has proteolytic activity and uses either ammonia or peptides as a source of $\mathrm{N}$ (ammonia-N user or producer). An in vitro experiment was conducted in batch cultures (50 mL media) to test the effect of the 3 strains cultured with $2 \mathrm{~N}$ sources supplied at 2 levels ( $\mathrm{n}=3 \times 2 \times 2$ conditions and 3 replicates) on $\Delta{ }^{15} \mathrm{~N}_{\text {bacteria-substrate. }}$ Organic (tryptone casein) and inorganic (ammonium chloride) $\mathrm{N}$ sources were supplied at low $(1 \mathrm{mM})$ or high $(11.5 \mathrm{mM})$ concentrations added to a culture medium containing $2 \mathrm{mM}$ of ammonia- $\mathrm{N}$ as the baseline level. After $48 \mathrm{~h}$ of incubation at $39^{\circ} \mathrm{C}$, the fermentation was stopped by placing the bottles in ice and the content collected for $\mathrm{N}$ isotopic analyses from the bacterial pellet obtained through differential centrifugation.

\section{Results and Discussion}


Both the $\mathrm{N}$ level (high vs low) and source (ammonia vs protein) influenced the $\Delta^{15} \mathrm{~N}_{\text {bacteria- }}$ substrate values (Figure 1; $P<0.001$ ) but in a different way depending on the specific bacterial $\mathrm{N}$ metabolism (Bacteria $\times \mathrm{N}$ source $\times \mathrm{N}$ level interaction effect; $P<0.001$ ). When the $\mathrm{N}$ level shifted from low to high the $\Delta^{15} \mathrm{~N}_{\text {bacteria-substrate }}$ increased $(P<0.001)$, except with $F$. succinogenes growing on ammonia (Bacteria $\times \mathrm{N}$ level interaction effect; $P<0.001$ ). Overall, our results agree with the higher $\Delta^{15} \mathrm{~N}$ observed in ruminants fed high vs low $\mathrm{N}$ diets (Cantalapiedra-Hijar et al., 2018) and partially confirm that the extent of ammonia uptake and release strongly affects the $\mathrm{N}$ isotopic signature of rumen bacteria. When the ammonia-consumer bacterium $F$. succinogenes was grown on ammonia, the $\Delta^{15} \mathrm{~N}_{\text {bacteria-substrate }}$ showed the lowest values $(P<0.001)$ in agreement with previous in vitro results on cellulolytic rich mixed-cultures grown on ammonia (Martinez-Fernandez et al., 2018). However, we did not observe higher $\Delta^{15} \mathrm{~N}_{\text {bacteria-substrate values when hyper-ammonia-producing }}$ $C$. aminophilum and proteolytic $P$. ruminocola were grown on protein as compared to ammonia.

Figure 1. Nitrogen isotopic signatures $\left(\Delta^{15} \mathrm{~N}_{\text {bacteria-substrate }}\right)$ among rumen bacteria grown on 2 different $\mathrm{N}$ sources (tryptone casein vs ammonium chloride) at 2 different $\mathrm{N}$ levels (Low [1 mM] and High [11.5 mM]). Bars having one or more letters in common are not statistically different from each other $(\mathbf{P}<0.05)$.

\section{Conclusions}

Our results showed that $\mathrm{N}$ isotopic signatures in rumen bacteria depend on their $\mathrm{N}$ metabolism. In particular, a strong ${ }^{15} \mathrm{~N}$ depletion occurred when a bacterium specialised in ammonia assimilation was grown.

\section{Acknowledgements}

This study has been possible thanks to the "INRA-CSIRO” linkage programme

\section{References}

Cantalapiedra-Hijar G., Dewhurst R., Cheng L., Cabrita A.R.J., Fonseca A., Nozière P., Makowsky D., Fouillet H., Ortigues-Marty I. 2018. Nitrogen isotopic fractionation as a biomarker for nitrogen use efficiency in ruminants: A meta-analysis. Animal 12(9): 1827-1837

Cantalapiedra-Hijar G., Fouillet H., Huneau J.F., Fanchone A., Doreau M., Nozière P., Ortigues-Marty I. 2016. Relationship between efficiency of $\mathrm{N}$ utilization and isotopic $\mathrm{N}$ fractionation in dairy cows: digestion or metabolism? Animal 10: 221-229

Martinez-Fernandez G., Cantalapiedra-Hijar G., Morgavi D.P., McSweeney C.S. 2018. Nitrogen isotopic signatures in mixed rumen cellulolytic bacteria differ depending on the nitrogen source. In: Proceedings of the 10th International Symposium on the Nutrition of Herbivores 